Elżbieta $\dot{Z} A K$

Uniwersytet Jagielloński

e.zak@wschodnia

\title{
MIEJSCE KULTURY SOWIECKIEJ W KSZTAŁTOWANIU ŚWIADOMOŚCI ZBIOROWEJ WSPÓŁCZESNYCH ROSJAN
}

ABSTRACT Место советской кумьтуры в формировании комлективного сознания жителей современной России

В настоящей статье обращается внимание на советскую культуру, представменную как подбор определенных культурных кодов, которые формировамись в условиях централизированной государственной культурной политиги и поэтому остались узнаваемыми. Эти коды уже тогда в коммективном сознании приобретали многозначный смысл, с одной стороны официальный, Аопускаемый цензурой, но одновременно народ обогащац их своим переносным смыслом, более универсальным. Подбор такого рода кодов поможил основу Аля целой сферы культуры повседневной жизни, своеобразие которой в долговременной перспективе воспринимается все более положительно. Ссылки, ностацьгия, воспоминания о советских временах начинают в сегодняшней России занимать все больше места в формировании современной русской идентисности, обеспечивая чувство своеобразности и инАивидуальности в контрасте к западной культуре. Раньше подобные культурные коды играли роль «медиаторов» (понятие Марка Аиповецкого) - становились точкой прикосновения Аля официальной и неофициальной сфер, однако в настоящее время эмементы советской культуры оказамись на стыке Авух противоположных измерений - узнаваемой и однообразной культуры жителя СССР и туманной, запутанной действительности гражАанина сегодняшней России. Все чаще появляются голоса, что советская культура вместе с ее мифами превращается в основополагающую часть Аля сегодняшней русской тождественности. Вышеуказанные тезисы в настоящей статье илюстрируются примерами в области кино-кодов (фигура 
Штирлица), телепрограмм (Старал квартира, Старые песни о главном), проекта Намедни. Наша эра и других.

Keywords: советская культура, культурные коды, комлективное сознание, русская социокультурная идентификация, Штирлиц, ностальгия по СССР, Намедни

Słowa kluczowe: kultura sowiecka, kody kulturowe, świadomość zbiorowa, Stirlitz, trickster, nostalgia za ZSRR, Namiedni, Parfionow, człowiek sowiecki

K ultura, która wykształciła się w czasach Związku Radzieckiego, należała do kultur „zamkniętych”, jeśli chodzi o zdolność do świadomego poddawania się czy też nieulegania oddziaływaniu obcych formacji kulturowych. Teresa Walas posługuje się dobitną metaforą knebla w odniesieniu do treści, które zostały objęte „blokadą wysłowienia" w literaturze i sztuce ery socjalizmu ${ }^{1}$.

Jednakże z perspektywy czasu można stwierdzić, iż pozytywnym efektem ubocznym działania owego knebla stało się stworzenie kultury jednorodnej, czytelnej oraz rozpoznawalnej dla wszystkich, pewnego wspólnego rdzenia obecnego w świadomości zbiorowej. Można było albo się poddać jego oddziaływaniu, albo wyrażać swój sprzeciw, albo też zachowywać ironiczny dystans, w czym dopomagały liczne powstające wówczas anegdoty. Rzeczywistość tamtych czasów została poddana całkowitej mitologizacji, pewnego rodzaju zaszyfrowaniu, kiedy to pojęciom przypisywano inne znaczenia, w mniejszym bądź większym stopniu przyjmowane. Mit, z którym obcowali członkowie społeczeństwa Związku Radzieckiego, jak stwierdza Mark Lipowiecki, wykroczył poza umowny obszar fikcji i baśni - stał się konstantą życia codziennegо: Тоталитарной власти нужна не сказка, а миф как конструкт реальности, как то, что окружено верой и принимается как «высшая» правда. Именно на тотальности мифологизации и строится могущество этой власти 2 . Z dzisiejszеgo punktu widzenia można stwierdzić, iż ze względu na siłę oraz skalę oddziaływania owe mity de facto stwarzały wspólny kod komunikacji kulturowej, zamkniętą sferę porozumienia pomiędzy członkami tego społeczeństwa. Wychodząc z takiego rozumowania, Swietłana Bojm w swojej książce Miejsca wspólne. Mitologia życia codziennego (Обшие места. Мифология повседневной жизни, 2002) $^{3}$ podjęła próbę zarysowania owej mitologii - archeologii powszedniości w Związku Radzieckim, charakteryzując te elementy, które stały się podstawowymi składowymi świadomości zbiorowej osób żyjących wówczas i określiły ich egzystencję.

Zob. T. Walas, Zrozumiećswój czas. Kultura polska po komunizmie. Rekonesans, Kraków 2003, s. 90-91.

2 М. Аиповецкий, Буратино: утопия свободной марионетки, [w:] Веселье человечки: культурные герои советского детства, red. И. Кукулин, М. Аиповецкий, М. Майофис, Москва 2008, s. 141.

3 Zob. С. Бойм, Общие места. Мифология повседневной жизни, Москва 2002. 
Tekst ma na celu rzucenie światła na kulturę sowiecką, pojmowaną jako zbiór określonych kodów kulturowych, zrodzonych w warunkach sterowanej polityki kulturalnej. Owe kody już wówczas $\mathrm{w}$ świadomości zbiorowej przybierały znaczenie wielowymiarowe, niosły przesłanie dwuznaczne: oficjalne, dopuszczane przez odgórne wytyczne, oraz przenośne, powstające w procesie odbioru. Zbiór podobnych kodów stał się bazą dla stworzenia całej sfery kultury życia codziennego, której specyfika wraz z upływem czasu zaczyna być postrzegana coraz bardziej pozytywnie (nie bez znaczenia pozostaje fakt, iż dla wielu okres ten pokrywał się z idealizowanymi czasami młodości) i odgrywa istotną rolę w budowaniu obecnej tożsamości zbiorowej w Rosji. Przywoływane wciąż elementy kultury sowieckiej zapewniają Rosjanom poczucie odrębności oraz indywidualności w kontraście do kultury Zachodu.

Wytworzone w kulturze sowieckiej kody w rzeczywistości Związku Radzieckiego mogły pełnić funcję „mediatorów” (pojęcie Marka Lipowieckiego) - łączników pomiędzy sferą oficjalną i nieoficjalną, a obecnie stają się pomostem pomiędzy rozpoznawalną i jednolitą kulturą, z którą identyfikował się obywatel ZSRR, a polifoniczną rzeczywistością mieszkańca dzisiejszej Rosji.

Warto wesprzeć się przykładem owej mediacji kulturowej, na którą wielokrotnie wskazuje Mark Lipowiecki, poprzez ilustrację fenomenu popularności mitu, w jaki przerodziła się postać Maksima Isajewa - Stirlitza. Ów kultowy bohater, który pojawił się w świadomości zbiorowej Rosjan czasów Breżniewa, zawładnął zróżnicowanymi warstwami społecznymi. W procesie recepcji mógł przyjmować funkcję mediato-

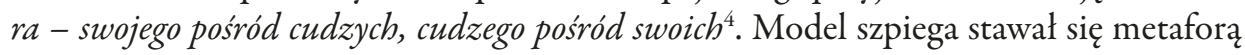
ukrywania się, balansowania pomiędzy pozorną służbą systemowi a życiem w zgodzie z własnym sumieniem. Jak twierdzi Mark Lipowiecki, Stirlitz stwarzał symboliczne alibi idealnego inteligenta sowieckiego, a odbiorca mógł znajdować w nim potwierdzenie tego, iż można czemuś służyć, ale się z tym nie utożsamiać, czy na odwrót: można do czegoś przynależeć, ale $\mathrm{w}$ istocie służyć czemuś innemu ${ }^{5}$. Tym samym postać ta odgrywała rolę mitu o mediatorze-inteligencie, stała się podwójnym kodem, w szczególności dla środowiska inteligenckiego, jako symbol dwuznaczności w działaniach i ambiwalencji. Stirlitz eksploatuje mitologię sowiecką Wielkiej Wojny Ojczyźnianej, a jednocześnie pełni funkcję antysowieckiego emigranta wewnętrznego. Ponadto w warunkach krytyki Zachodu i wykształconej tam kultury mieszczańskiej mediator Stirlitz, dysydent-inteligent ukrywający się pod postacią oficera NKWD, łączy w sobie zachodni styl życia z rodzimym - sowieckim.

Dobitnym przykładem społecznego „życia” owego bohatera na kolejnym etapie są cykle dowcipów, pełne ironii, parodii, jaka się w nich objawia. Dzięki nim jego obecność stała się w dwudziestowiecznej kulturze rosyjskiej jeszcze bardziej wyrazista. Fakt, iż dowcipy o tym bohaterze, które zaczęły powstawać tuż po ukazaniu się filmowej

4 М. Аиповецкий, Президент Штирлии, „Искусство кино” 2000, nr 11, s. 76; na ten temat szerzej zob. także: tenże, Искусство алиби: „Семнадцать мгновений веснь” в свете нашего опьта, „Неприкосновенный запас” 2007, nr 3, [online] http://magazines.russ.ru/nz/2007/3/li16.html, 12 IV 2012.

5 Tenże, Президент Штирлиц..., s. 74. 
ekranizacji powieści Siedemnaście mgnień wiosny (Семнадцать мгновений весньь), czyli w latach 70., funkcjonują nadal w obiegu społecznym, świadczy o tym, jak jest on żywotny. Zmienia się wszak jego odbiór. Wizerunek tej postaci w stosunku do prototypu książkowego oraz filmowego podlega nieustannym modyfikacjom, choć bazuje na wielości znaczeń, jaka kształtowała się w rzeczywistości Związku Radzieckiego. Przestaje być uosobieniem honoru, patriotyzmu, nieszczęśliwego inteligenta. W części anegdot występuje jako osoba ograniczona i niezbyt błyskotliwa (słynny dowcip: Stirlitz pomyślał, spodobało mu się i pomyślał jeszcze raz). W twórczości ustnej oraz w Internecie dowcipy są uwspółcześniane, zatem bohater może być przedstawiony jako kombinator, skacowany więzień czy też obserwator homoseksualistów ${ }^{7}$. Jednakże wielość sensów nakłada się na element kultury, który został powołany do życia w Związku Radzieckim oraz na różnych etapach ulegał modyfikacjom.

Mark Lipowiecki ukazuje również jeszcze istotniejszą funkcję, jaką spełniały niektóre ówczesne elementy kultury oficjalnej - rolę trickstera. Archetyp trickstera wskazuje na przeciwstawianie się ustalonym normom i porządkom, łamanie konwencji i powszechnie przyjętych zasad, niezależność. Jednocześnie trickster nie jest amoralny, ale pozostaje poza przyjętą ogólnie moralnością, gdyż nie wchodzi w jeden system wartości, łamie, przekracza, wyśmiewa granice między przeciwieństwami; przykładem może być Ostap Bender czy też bohaterowie kreskówek sowieckich: Trubadur, Winni-Puh, Szapokliak, Buratino. Postacie te, tricksterzy, stanowiąc kontrast do jednoznacznie pozytywnego bohatera sztuki socrealistycznej, naiwnego, zmodyfikowanego Iwianuszki-Duraczka, okazały się ulubieńcami odbiorcy rosyjskiego - sowieckiego oraz postsowieckiego. Sowiecki trickster, czego dowodzi Mark Lipowiecki: по-видимому, наиболее адекватно воплотил силу иинизма, необходимого для выжкивания в постоянно меняющихся, непонятных и непрозрачных социальныхх условиях советского общества, отражал - в комической, игровой форме - ту реальную сочиальность, которая сложилась в результате большевистского эксперимента и которая не вписыьвалась в бинарныце структуры как офищиального советского, так и неофициальньх дискурсов ${ }^{8}$.

Obecnie w kulturze po etapie dekonstruującego postmodernizmu, kiedy konceptualizm oraz soc-art straciły na znaczeniu, wzmacniła się nostalgia, nastąpiło przejście

6 Jeden z głównych typów anegdot dotyczy ironicznego traktowania Maksima Isajewa jako superagenta. Na kształt owych żartów miała wpływ nietypowa konstrukcja serialu Siedemnaście mgnień wiosny (Семнадизать мгновений весныь), w którym zamieszczone zostały nie tylko obszerne fragmenty tekstu komentarza wypowiadanego spoza kadru jednostajnym charakterystycznym głosem narratora - aktora Jefima Kopielana, ale też na ekranie pojawiają się, bezpośrednio w formie tekstu, wstawki przeznaczone dla Stirlitza: Informacja do przemyślenia. Stąd też część anegdot nawiązuje do niezwykle spowolnionego, jak na opowieść o szpiegu, toku akcji. Niektóre z nich parodiują jego sposób działania, polegający na bezruchu oraz zamyśleniu.

7 Штирлии выбрался на пикник. Красота! Аес, река, вдали на опушке - голубые ели. Штирлии подомел поблике - голубье есть перестали - nieprzetłumaczalna gra słów gotubyje jeli - „niebieskie jodły” oraz jednocześnie - „gejowie jedli”.

8 М. Аиповецкий, Трикстер и „закрытое” общество, „НАО” 2009, nr 100, [online] http:// magazines.russ.ru:8080/nlo/2009/100/li19-pr.html, 20 IV 2012. 
do nowego realizmu czy też etapu „nowej szczerości” i „nowego sentymentalizmu”. Konceptualizm oraz soc-art na tworzywie mitów i rozpoznawalnych powszechnie elementów epoki minionej tworzył ich parodie, szydząc z pomocą ironii i satyry z sowieckich schematów, klisz, stereotypów, metod twórczych oraz sposobu myślenia. W swoim czasie odegrał istotną rolę, ale nie stał się estetyką dominującą, entuzjastycznie przyjętą oraz zrozumiałą. Został wyparty przez nowy nurt nostalgicznie zwracający się w stronę odrzuconej emocjonalności, pozbawionej drwiny opowieści o humanizmie.

W kontraście do wizji rzeczywistości przestępczej po roku 1991, rozczarowania zmianami, jakie zaszły w Rosji przełomu XX i XXI w., załamania się poprzedniego systemu wartości, z maksymalistycznych uogólnień czerpie odradzająca się nostalgia za czasami Związku Radzieckiego. Jelena Baraban podkreśla, iż rosyjska świadomość zbiorowa drugiej połowy lat 90. zaczęła idealizować spokój, zwyczajność, przyjaźń i relacje między ludźmi tamtych czasów, wypierając negatywne elementy, tarcia i bolączki owej rzeczywistości. Badaczka potwierdza, iż działa w tym wypadku mechanizm budzenia się nostalgii nie za konkretnym porządkiem rzeczy, ale za mitem przeszłości, radosnej młodości, zdolnością do przeżywania piękna utopii, do optymizmu i okłamywania samego siebie, tęsknoty za tym, co rzekomo zostało zaprzepaszczone w teraźniejszości'. Coraz częściej w społeczeństwie rosyjskim pobrzmiewają pozytywnie oceny epoki Breżniewa nie jako czasów zastoju, ale „stabilizacji”. Publicysta Dmitrij Olszanskij posługuje się terminem „breżniewowski humanizm”, twierdząc, iż najistotniejsze w ostatnich latach Związku Radzieckiego było to, iż bycie starym i biednym, niepozornym i niezbyt pięknym, nieudacznikiem w niesprzyjających warunkach nie stanowiło powodu do wstydu. W świecie obecnym natomiast sytuacja się odwróciła - każdy jest zobowiązany do tego, by być człowiekiem sukcesu, bogatym, młodym i pięknym ${ }^{10}$.

Borys Dubin w prowadzonych analizach przemian społeczno-kulturowych podkreśla, iż zgodnie z danymi z roku 2004 niemal jedna czwarta badanych obywateli rosyjskich nie może dostosować się do zmian, jakie zaszły w Rosji ${ }^{11}$. W tym też roku $68 \%$ przebadanych oświadczyło, iż żałuje rozpadu Związku Radzieckiego, przy czym można zauważyć wyraźnie zróżnicowane w zależności od przedziału wiekowego - pośród osób powyżej 55 roku życia było to $83 \%{ }^{12}$. Nostalgia budzi się w członkach społeczeństw, których droga życiowa, jak to ujmuje Zygmunt Bauman, jest naznaczona odrzuconymi i straconymi tożsamościami $i^{13}$.

9 Zob. Е. Барабан, Детективы Александры Марининой, или „Старые мотивы - новые песни”, [w:] Творчество Александры Марининой как отражение современной российской ментальности, red. Е. И. Трофимова, Москва 2002, s. 100.

10 Zob. wypowiedź publicysty przytoczona w tekście: Брежнев-2 - для автохтонов, Путин №3 - для либералов, [online] http://www.newsland.ru/news/detail/id/800708/, 12 IV 2012.

11 Borys Dubin powołuje się na badania przeprowadzone przez Centrum Analityczne im. Jurija Lewady, wcześniej znane jako ВЦИОМ. Zob. Б. Аубин, Читатель в обществе зрителей, „Знамя” 2004, nr 5, [online] http://magazines.russ.ru/znamia/2004/5/dub9.html, 12 IV 2012.

12 Zob. tenże, Россия нулевьх: политическая культура-историческая память-повседневная жизнь, Москва 2011, s. 32-33.

13 Tamże, s. 62. 
We współczesnej Rosji nostalgia za niedawną przeszłością stała się jednym z elementów kształtujących stylistykę gatunkową programów telewizyjnych. Natalia Iwanowa podkreśla, iż telewizja w Rosji stała się ważniejszą ze sztuk, odsunęła na drugi plan kulturę słowa, przejmując czytelników książek, a także periodyków literackich. I właśnie na ekranie telewizora, co podkreśla rosyjska krytyk literatury, Светлое будущее, так и не осуществленное в жизни, приходит на телеэкраны как светлое прошлое ${ }^{14}$. Efektem oraz jednocześnie budulcem owej nostalgii za kulturą sowiecką są powtarzane notorycznie filmowe szlagiery epoki minionej, przenoszące w świat pocieszającej przewidywalności i spokoju, a jednocześnie radości. Są rozpoznawalne, odbierane jako swój świat, obecnie podlegający destrukcji. Stwarzają obraz niejakiej romantyki tamtych czasów tym bardziej utopijnie wyostrzonej, że rodzącej się w zderzeniu z brutalizmem czasów obecnych, rozczarowaniami demokracją, poczuciem zagubienia i niepewności.

Jako przykłady zasadniczej roli przeszłości czasów Związku Radzieckiego w dyskursie publicznym oraz sposobu wykorzystania stworzonej wówczas kultury, wciąż obecnej w świadomości zbiorowej, posłużą trzy symptomatyczne dla Rosji lat 90. cykle programów telewizyjnych, które nie mają odpowiedników w produkcji zachodniej. Są one wynikiem niejakiego kryzysu tożsamości kulturowo-historycznej byłego społeczeństwa sowieckiego, a powracają do czasów, z którymi związane jest życie oraz pamięć wielu obecnych odbiorców. Mogą posłużyć jako ilustracja nastrojów społecznych, gdyż, wedle określenia Johna Fiske i Johna Hartleya, telewizja to bard wspótczesnych spoteczeństw $w^{15}$ z za pośrednictwem tego barda zachodzą, czy też wzmacniane są, procesy budowania tożsamości.

Pierwszy z programów, autorstwa dramaturga Grigorija Gurwicza, to cykl Stare mieszkanie (Старал квартира) ${ }^{16}$, w którym osoby obecne na scenie ucharakteryzowanej na czasy Związku Radzieckiego wspólnie z głosami z widowni zasiadającej w studio opowiadały historie $\mathrm{z}$ tamtych czasów. Wspomnienia rzeczywistości sowieckiej z wielu różnych perspektyw tworzyły „kronikę dnia”. Natalia Iwanowa nazywa podobnego typu stylistykę i gatunek przenośnie „stypą” (поминки). Przy czym owa „stypa” ma wydźwięk optymistyczny oraz polemiczny, jeśli chodzi o stosunek do dziedzictwa niedawnej przeszłości - w kontraście do stylu zwanego чернухо й, z obsceniczno-rozliczeniowym charakterem literatury czasów pieriestrojki i głasnosti ${ }^{17}$.

Drugim przykładem jest cykl autorstwa Konstantina Ernsta i Leonida Parfionowa Stare pieśni o najważniejszym (Старые песни о главном) - seria noworocznych filmów muzycznych emitowanych w latach 90. w 1 programie rosyjskiej telewizji, które cieszyły się wówczas ogromną popularnością w Rosji. Do projektu zostali zaangażowani znani artyści rosyjskiej popkultury, a bazował on na wykorzystaniu popularnych piosenek z różnych dziesięcioleci Związku Radzieckiego. Każda część stylizowana była na

14 Н. Иванова, Ностальящее. Собрание наблюдений, Москва 2002, s. 58.

15 Cyt. za: W. Kuligowski, Popkultura jako źródto tożsamości, [w:] Kultura popularna. Graffiti na ekr@ nie, red. W. Godzic, Kraków 2002, s. 22.

16 Program w latach 90 . był emitowany raz w miesiącu w rosyjskim programie telewizyjnym RTR.

17 Н. Иванова, Ностальящее..., s. 64. 
określoną epokę - począwszy od lat 40. i 50., przez lata 60., 70. i początek lat 80., aż do części czwartej Stare pieśni o najistotniejszym. Postscriptum (Старьц песни о главном. Постскриптум), w której zazębiały się wszystkie okresy, w tym także współczesność.

Jak stwierdza Leonid Parfionow: żyjemy w epoce renesansu antyczności sowieckiej ${ }^{18}$ stąd też zrodziła się idea stworzenia trzeciego z komentowanych w tym miejscu cykli: Niedawne dni. Nasza era (Намедни. Hаша эра), obejmującego reportaże od roku 1961 aż do 2005 poświęcone sowieckim fenomenom, wydarzeniom oraz mitom ${ }^{19}$. Niedawne dni 1961-2003: Nasza era (Намедни 1961-2003: Hаша эра) to nazwa cyklu dokumentalnych programów telewizyjnych pokazujących w porządku chronologicznym wydarzenia danego roku, które w największym stopniu koncentrowały uwagę społeczeństwa, najpierw sowieckiego, a od roku 1991 - rosyjskiego ${ }^{20}$. Ich autorem i prowadzącym był Leonid Parfionow. Umiejętne połączenie faktów historycznych, opinii ekspertów, uwag krytycznych z nostalgiczno-ironicznymi wspomnieniami sprawiło, iż cykl stał się jednym z najbardziej udanych materiałów dokumentalnych nie tylko kanału NTV, ale i całej telewizji rosyjskiej, choć jego twórca został zwolniony z pracy w telewizji, a program w konsekwencji zawieszony. Sukces cyklu sprawił, że Leonid Parfionow rozpoczął w roku 2007 pracę nad projektem książkowym pod tym samym tytułem. Pierwszy tom ukazał się już pod koniec następnego roku. Całe czteroczęściowe wydanie cieszyło się taką popularnością, iż u schyłku roku 2011 został wydany kolejny, piąty tom, obejmujący wydarzenia z lat 2001-2005 (Намедни. Наша эра. 2001-2005, Москва 2011). Książki mają charakter encyklopedycznego usystematyzowania różnego rodzaju elementów budujących rzeczywistość sowiecką, wykraczających poza obszar jedynie wydarzeń politycznych. W swój zakres włączają także takie sfery, jak moda, sport, motoryzacja, kulinaria, dostępne nowinki techniczne itp. Owe „kroniki” opatrzone fotografiami i komentarzem odnośnie do zasięgu społecznego oddziaływania danego zjawiska wyróżniają się atrakcyjną szatą graficzną oraz stylistyką. Stanowią nową propozycję spojrzenia na czasy Związku Radzieckiego jako na te, w których istniały elementy wspólne, wszystkim znane i konsolidujące, warunkujące jedność odczuwania, w tym także rozrywki, przyjemne składowe codzienności, odchodzące obecnie w zapomnienie. W konsekwencji wyzwalają pozytywne emocje w odniesieniu do epoki minionej.

W społeczeństwie rosyjskim początku XXI w. nasilająca się nostalgia za państwem sprzed rozpadu znajduje swój wyraz również w samym języku oraz w funkcjonujących w jego obrębie związkach wyrazowych. Wciąż funkcjonują neutralne, bądź nawet posiadające wydźwięk pozytywny, określenia: epoka sowiecka, sowieckie wykształcenie, sowiecki styl, sowiecki wystrój, wreszcie i ludzie sowieccy. Termin „kultura sowiecka” w rosyjskiej rzeczywistości językowej odnosi do okresu historycznego, uwarunkowań, rzeczywistości Związku Radzie ckiego (Советского союза), nie obarczo-

18 А. Парфенов, Намедни. Наша эра. 1961-1970, Москва 2010, s. 6.

19 Zob. http://krasview.ru/series/NamedniNashaera, 17 II 2012, a także wywiad z L. Parfionowem po ukazaniu się piątego tomu: М. Эйдис, „Если бояться, то надо менять профессию”. Вьхходит пятый том митературного проекта „Намедни. Наша эра. 2001-2005”, [online] http://www.gazeta.ru/ culture/2011/11/23/a_3845374.shtml, 17 II 2012.

20 Program był emitowany przez rosyjski kanał NTV w okresie od 1 III 1997 do 28 XII 2003 r. 
ny jest a priori sensem ideologicznym, poddawanym zdecydowanej krytyce. Co więcej, przymiotnik „sowiecki” wykorzystywany jest często do celów marketingowych, przy reklamie danego towaru, a chwyt ów - zgodnie ze słowami Pawła Czistiakowa, kierownika działu marketingu nowosybirskiej firmy „Guliwer” - nawet zwiększa poziom sprzedaży, wzbudzając pozytywne społeczne emосје: Прием использования советской символики, слова „советский в продажах не нов, используется не первьий год. Во-первьцх, это обращение $к$ нашему прошлому, а у многих прошлое вызывает какие-то положительные эмочии, воспоминания. Аюди хотят соприкасаться с этим ощущением ${ }^{21}$.

Tymczasem w polskiej rzeczywistości językowej ze względu na uwarunkowania historyczne określenie „sowiecki” posiada konotacje jednoznacznie pejoratywne. Często $\mathrm{w}$ połączeniu z typem osobowościowym kojarzony jest także (a nawet utożsamiany) $\mathrm{z}$ określeniem homo sovieticus ${ }^{22}$, wyzwalającym tym bardziej negatywne skojarzenia. W rzeczywistości wszak, co podkreśla Michaił Heller, trudno jest przeprowadzić tak kategoryczne kwalifikacje: homo sovieticus $w$ czystym wydaniu spotyka się stosunkowo rzadko. Homo sovieticus to zespót cech i rysów, występujacy - w różnych proporcjach u wszystkich ludzi zamieszkujacych Związek Sowiecki i oddychających jego powietrzem ${ }^{23}$. Podobnie Józef Tischner zastrzega, iż: Oczywiście, owo pojęcie jest pewna abstrakcją, która nigdy i nigdzie nie urzeczywistnia się $w$ catej petni, znajduje jednak swój czastkowy odpowiednik w kazdym spoteczeństwie, poddanym przez dostatecznie dtugi okres ideologicznemu szkoleniu komunizmu².

Obecnie, po 20 latach od zmiany systemowej, pojawia się w Rosji stopniowo coraz więcej badań poświęconych fenomenowi „człowieka sowieckiego”, wystarczy posłużyć się przykładem projektu Instytutu Lewady z 1993 r. Sowiecki zwykty cztowiek (Cоветскиŭ простойчеловек). Natomiast, co istotne, w rosyjskim dyskursie kulturologicznym powstały dwa skontrastowane określenia: советский і совковыцй (совок), różnicujące podejście do niełatwego dla Rosjan tematu, jakim jest niedawna przeszłość Związku Radzieckiego oraz jej rzetelna, wyzbyta emocji ocena. Słowo sowok w języku rosyjskim oznacza „szufelkę”, a przedmiot ów, jeśli uczynić go symbolicznym określeniem typu człowieka tamtych dni (Аучший инструмент - лопата, если человек - совок), przyрisuје mu jednoznacznie negatywne cechy. Wówczas stanowi epitet dla osoby, którą cechuje, m.in.: bezwolność, podporządkowanie, uzależnienie od ideologii systemu, tępota, bierność. W kontekście powyższego ujęcia następują próby wartościowania zjawisk i postaw społecznych mają-

21 Hостальгия no СССР, [online] http://www.dela.ru/news/other/24989/, 12 IV 2012.

22 Tę nazwę typu antropologicznego wprowadził do dyskursu krytycznego w $1982 \mathrm{r}$. Aleksandr Zinowiew w książce pod takim właśnie tytułem - Гомо советикус (Lausanne 1982), realizując potrzebę krytycznej oceny podstawowych zjawisk, które wpłynęły na model człowieka kształtowanego przez warunki egzystencji w Związku Radzieckim, oraz przewartościowania podstawowych pojęć, zafałszowanych przez tamtejszą propagandę. Na gruncie polskim upowszechnił ów termin Lucjan Suchanek w książce Homo sovieticus. Świetlana przysztość, gnijacy Zachód. Pisarstwo Aleksandra Zinowiewa, Kraków 1999, Literatura Rosyjska - Emigracja - Tamizdat - Samizdat, 8, następnie Józef Tischner, Etyka solidarności oraz Homo sovieticus, Kraków 2005.

23 M. Heller, Maszyna iśrubki. Jak hartowat się cztowiek sowiecki, Warszawa 1989, s. 13.

24 J. Tischner, Etyka solidarności..., s. 141. 
cych swą genezę w obalonym ustroju. W prowadzonych dyskusjach również wybrzmiewają takie rozróżnienia językowe: Когда сформировался советский человек и когда он стал превращаться в "совка"?, Советскал власть ушла, но „совок” остался; советским можно перестать бъцть, но нельзя перестать бъцть „совком" ${ }^{25}$.

W symboliczny sposób istniejącą wciąż problematyczność w percepcji przeszłości sowieckiej pośród społeczeństwa rosyjskiego przełomu tysiącleci odzwierciedla symptomatyczny incydent, do jakiego doszło w Moskwie w roku 2009. Dotyczył on oburzenia z powodu nazwy baru, która zawierała w przymiotnik ,antysowiecki” - Антисоветская чебуречная; рojawiła się ona w kontraście do istniejących w Moskwie innych punktów barowych z określeniem „sowiecki” w nazwie - Советская чебуречная. Moskiewska Rada Weteranów zwróciła się do władz Północnego Okręgu Administracyjnego Moskwy ze skargą w związku z nazwą, która obraża uczucia obywateli, pozytywnie odnoszących się do przeszłości sowieckiej. W efekcie, po ingerencji władz, nazwa została zmieniona ${ }^{26}$. Powyższa historia wywołała $\mathrm{w}$ społeczeństwie spory na temat weteranów prawowiernych i nieprawowiernych, tych, którzy są godni szacunku, oraz tych, którzy na niego nie zasługują. Jeszcze nie tak dawno podobna dyskusja nie byłaby możliwa. Zatem kwestią czasu zapewne pozostaje także rzetelne przepracowanie dziedzictwa czasów sowieckich, w momencie, kiedy nostalgia okrzepnie, nastąpi zmiana pokoleń, a na przeszłość będzie można spojrzeć z badawczo-krytycznym dystansem.

\section{BIBLIOGRAFIA}

Барабан Е., Детективы Александры Марининой, или „Старьеемотивь - новые песни”, [w:] Творчество Александры Марининой как отражение современной российской ментальности, red. Е. И. Трофимова, Москва 2002.

Бойм С., Общие места. Мифология повседневной жизни, Москва 2002.

Брежнев-2 - для автохтонов, Путин №3 - длялибералов, [online] http://www.newsland.ru/ news/detail/id/800708/.

Аубин Б., Читатель в обществе зрителей, „Знамя” 2004, nr 5, [online] http://magazines. russ.ru/znamia/2004/5/dub9.html.

Аубин Б., Россия нулевых: политическал культура-историческал память-повседневная жизнь, Москва 2011.

Эйдис М., „Если болтыся, то надо менять профессию”. Выхходит пятьй том митературного проекта „Намедни. Нама эра. 2001-2005”, [online] http://www.gazeta.ru / culture/2011/11/23/a_3845374.shtml.

25 Kwestia omawiana w wielostronnej dyskusji na antenie radia Svoboda, Советский человек: 10 отличий от современного, [online] http://www.svobodanews.ru/content/feature/24323622.html, 2 IV 2012.

26 Ślady owej pełnej emocji dyskusji można znaleźć m.in. na stronach: http://lomonosov.livejournal. com/19790.html, http://reformam-net.narod.ru/Moskva/podrabinek.html, http://www.svobodanews.ru/content/blog/1836554.html oraz w artykule A. Podrabinieka zatytułowanym Jak cztowiek antysowiecki ludziom antysowieckim: А. Полрабинек, Как антисоветчик антисоветчикам, „Ежедневой журнал” 2009, 21 IX, [online] http://www.ej.ru/?a=note\&id=9467, 20 IV 2012. 
Heller M., Maszyna iśrubki. Jak hartowat się cztowiek sowiecki, Warszawa 1989.

Иванова Н., Ностальящее. Собрание наблюдений, Москва 2002.

Kuligowski W.,Popkultura jako źródto tożsamości, [w:] Kultura popularna.Graffiti na ekr@nie, red. W. Godzic, Kraków 2002.

Аиповецкий М., Буратино: утопия свободной марионетки, [w:] Веселье человечки: культурныц герои советского детства, red. И. Кукулин, М. Аиповецкий, М. Майофис, Москва 2008.

Аиповецкий М., Искусство алиби: „Семнадиать мгновений веснь” в свете нашего опыта, „Неприкосновенный запас” 2007, nr 3, [online] http://magazines.russ.ru/nz/ 2007/3/li16.html.

Аиповецкий М., Президент Штирлии, „Искусство кино” 2000, nr 11.

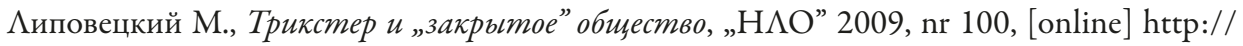
magazines.russ.ru:8080/nlo/2009/100/li19-pr.html.

Hocmasвгия no CCCP, [online] http://www.dela.ru/news/other/24989/.

Парфенов А., Намедни. Наша эра. 1961-1970, Москва 2010.

Подрабинек А., Как антисоветчик антисоветчикам, „Ежедневой журнал” 2009, 21 IX, [online] http://www.ej.ru/?a=note\&id=9467.

Ронен О., Совок, „Звезаа” 2007, nr 11, [online] http://magazines. russ.ru/zvezda/2007/11/ ro14.html.

Советский человек: 10 отличий от современного, [online] http://www.svobodanews.ru/content/feature/24323622.html.

Suchanek L, Homo sovieticus. Świetlana przysztość, gnijacy Zachód. Pisarstwo Aleksandra Zinowiewa, Kraków 1999, Literatura Rosyjska - Emigracja - Tamizdat - Samizdat, 8.

Tischner J., Etyka solidarności oraz Homo sovieticus, Kraków 2005.

Walas T., Zrozumieć swój czas. Kultura polska po komunizmie. Rekonesans, Kraków 2003.

Зиновьев А., Гомо советикус, Lausanne 1982.

http://krasview.ru/series/NamedniNashaera.

http://lomonosov.livejournal.com/19790.html.

http://reformam-net.narod.ru/Moskva/podrabinek.html.

http://www.svobodanews.ru/content/blog/1836554.html.

Dr Elżbieta ŻAK - absolwentka filologii rosyjskiej UJ. Pracownik Instytutu Rosji i Europy Wschodniej UJ (wykładowca języka rosyjskiego). Współzałożyciel i obecny prezes Stowarzyszenia Wschodnia Perspektywa. Praca doktorska pt. Bohater rosyjskiej popliteratury w powieściach A. Marininej i B. Akunina znajduje się w ostatniej fazie ukończenia. Zajmuje się współczesną kulturą rosyjską oraz zagadnieniem postsowieckiej świadomości zbiorowej. 